\title{
Optimasi Pembobotan pada Query Expansion dengan Term Relatedness to Query-Entropy based (TRQE)
}

\author{
Resti Ludviani $^{1}$, Khadijah F. Hayati ${ }^{2}$, Agus Zainal Arifin ${ }^{3}$, Diana Purwitasari ${ }^{4}$ \\ Program Studi Teknik Informatika, Fakultas Teknik Informatika, Institut Teknologi Sepuluh November \\ Jl. Sukolilo, Surabaya 60111, Jawa Timur \\ E-mail: ${ }^{1}$ restiludvi@gmail.com, ${ }^{2}$ dee.jafa@gmail.com, ${ }^{3}$ agusza@cs.its.ac.id, ${ }^{4}$ diana @if.its.ac.id
}

Masuk: 31 Desember 2014; Direvisi: 20 Januari 2015; Diterima: 21 Januari 2015

\begin{abstract}
An appropriate selection term for expanding a query is very important in query expansion. Therefore, term selection optimization is added to improve query expansion performance on document retrieval system. This study proposes a new approach named Term Relatedness to Query-Entropy based (TRQE) to optimize weight in query expansion by considering semantic and statistic aspects from relevance evaluation of pseudo feedback to improve document retrieval performance. The proposed method has 3 main modules, they are relevace feedback, pseudo feedback, and document retrieval. TRQE is implemented in pseudo feedback module to optimize weighting term in query expansion. The evaluation result shows that TRQE can retrieve document with the highest result at precission of $100 \%$ and recall of 22,22\%. TRQE for weighting optimization of query expansion is proven to improve retrieval document.
\end{abstract}

Keywords: TRQE, query expansion, term weighting, term relatedness to query, relevance feedback

\begin{abstract}
Abstrak..Pemilihan term yang tepat untuk memperluas queri merupakan hal yang penting pada query expansion. Oleh karena itu, perlu dilakukan optimasi penentuan term yang sesuai sehingga mampu meningkatkan performa query expansion pada system temu kembali dokumen. Penelitian ini mengajukan metode Term Relatedness to Query-Entropy based (TRQE), sebuah metode untuk mengoptimasi pembobotan pada query expansion dengan memperhatikan aspek semantic dan statistic dari penilaian relevansi suatu pseudo feedback sehingga mampu meningkatkan performa temukembali dokumen. Metode yang diusulkan memiliki 3 modul utama yaitu relevan feedback, pseudo feedback, dan document retrieval. TRQE diimplementasikan pada modul pseudo feedback untuk optimasi pembobotan term pada ekspansi query. Evaluasi hasil uji coba menunjukkan bahwa metode TRQE dapat melakukan temukembali dokumen dengan hasil terbaik pada precision $100 \%$ dan recall sebesar 22,22\%.Metode TRQE untuk optimasi pembobotan pada query expansion terbukti memberikan pengaruh untuk meningkatkan relevansi pencarian dokumen.
\end{abstract}

Kata Kunci: TRQE, ekspansi query, pembobotan term, term relatedness to query, relevance feedback

\section{Pendahuluan}

Jumlah informasi yang tersedia secara elektronik meningkat secara dramatis. Dalam melakukan pencarian informasi membutuhkan metode untuk mengidentifikasi dokumen yang relevan terhadap query user (Boston, 2014). Hanya saja, query user untuk me-retrieve dokumen sering kali terlalu pendek atau ambigu (Araujo, 2010). Aroujo menggunakan teknik query reformulation untuk meningkatkan hasil temu kembali (retrieval).

Ekspansi query (query expansion) dikenal juga dengan pengayaan query (query enrichment) digunakan untuk meningkatkan kinerja retrieval (Saneifar, 2014). Cara yang digunakan dengan merumuskan dan menambahkan term ke query awal (initial query) untuk memperjelas query. Sehingga diharapkan mampu menangani masalah ketidakjelasan query (disambiguate query). Diantara teknik ekspansi query yang mulai dikenalkan pada pertengahan 1960-an adalah relevance feedback (umpan balik relevansi). Relevance feedback adalah teknik 
dimana pengguna dapat memberikan informasi relevansi pada dokumen tertentu atau term query agar sistem menemukan tambahan dokumen yang relevan.

Terdapat beberapa jenis teknik relevance feedback, diantaranya adalah jenis eksplisit. Jenis eksplisit feedback dapat digunakan ketika penilai secara langsung mengetahui bahwa feedback yang diberikan relevan (Carpineto, 2001). Hal ini mengharuskan penilai memiliki informasi yang cukup. Hasil retrieval kurang sesuai jika penilai tidak dapat menilai feedback yang relevan.

Saneifar, dkk (2014) mengajukan pendekatan query expansion berbasis eksplisit dan pseudo relevance feedback yang baru dengan pembobotan yang disebut dengan TRQ (term relatedness to query). Pembobotan tersebut memberikan nilai pada term berdasarkan hubungannya dengan query. Metode TRQ memperhatikan aspek semantik dan statistik dengan menggabungkan lexical word frequency (lwf) dengan invers document frequency (idf). Saneifar juga mengembangkan metode tersebut menjadi $T_{R Q}$ ext. Hasil implementasi metode TRQ pada log file menunjukkan bahwa metode yang diajukan mampu meningkatkan performa passage retrieval.

Wu, dkk. (2013) menyatakan bahwa entropi dapat digunakan sebagai pengukuran seleksi fitur. Pada penelitiannya, mereka mengajukan pembobotan berbasis entropi dan memberikan hasil yang lebih baik dibandingkan dengan pembobotan TF.IDF. Pendekatan query expansion berbasis entropi mempertimbangkan distribusi term yang muncul dalam dokumen yang relevan dan tidak relevan hingga sampai pada nilai diskriminasi term. Oleh karena itu, dibutuhkan optimasi pseudo relevance feedback pada query expansion menggunakan konsep entropi untuk meningkatkan performa dokumen retrieval. Pada penelitian ini diajukan sebuah metode optimasi pembobotan yang memperhatikan aspek semantik dan statistik dari penilaian relevansi pseudo feedback sehingga mampu meningkatkan performa temu kembali dokumen. Metode yang diajukan ini disebut dengan TRQE (Term Relatedness to Query - Entropy based).

\section{Tinjauan Pustaka}

Manning (2008) menjelaskan dua tipe metode Query Expansion, yaitu: (1) global dan (2) teknik lokal. Metode global membutuhkan adanya lexical-semantic seperti ontologi. Metode global banyak digunakan dalam question answering (QA) dimana QA menggunakan basis pengetahuan untuk mengidentifikasi variasi leksikal dari term pertanyaan. Variasi tersebut digunakan untuk menganalisis dan mengambil jawaban yang relevan. Pada tahap ini, sistem biasanya melibatkan pengetahuan morfologi dan semantik dari kamus elektronik yang ada dan sumber informasi leksikal seperti WordNet. Pasca (2001) mengajukan metode query expansion dimana query diperluas menggunakan morfologi, derivasi leksikal, dan kesamaan semantik semacam sinonim yang sangat bergantung pada sumber informasi (resource). Selain itu, Agichtein (2001) mengusulkan query expansion berbasis web resources. Mereka mengambil sejumlah keyword dari pertanyaan awal untuk membentuk query yang diperluas dengan frasa yang cenderung terjadi dalam kalimat deklaratif yang mengandung jawaban.

Metode lokal, dikenal dengan relevance feedback, merujuk pada suatu proses interaktif yang membantu untuk meningkatkan performa temu kembali (Saneifar, 2014). Pada metode ini, ketika pengguna memasukkan query, sistem temu kembali informasi mengembalikan set awal dokumen hasil pencarian kemudian meminta pengguna untuk menilai apakah beberapa dokumen relevan atau tidak. Setelah itu, sistem merumuskan query berdasarkan penilaian pengguna, dan mengembalikan satu set hasil baru. Ada tiga jenis relevance feedback (Saneifar, 2014), yaitu: eksplisit, pseudo/semu (blind), dan implisit. Jenis eksplisit feedback dapat digunakan ketika penilai secara langsung mengetahui bahwa feedback yang diberikan relevan (Carpineto, 2001). Ketika tidak ada penilaian relevansi yang tersedia, sebagai alternatif, pseudo relevance feedback atau blind relevance feedback dapat dilakukan dengan mengasumsikan bahwa sejumlah kecil dokumen peringkat teratas (top-rank) dalam hasil pencarian awal yang relevan dan kemudian menerapkan umpan balik relevansi berdasarkan asumsi tersebut. Metode ini mampu melakukan analisis local secara otomatis. Selain relevance feedback dan psudo relevance feedback, terdapat implicit feedback, dimana tidak ada informasi langsung yang 
menunjukkan relevansi dokumen. Pada implisit feedback tindakan atau perilaku pengguna dalam berinteraksi dengan sistem digunakan untuk menyimpulkan informasi kebutuhan pengguna. Perilaku pengguna tersebut misalkan lamanya waktu yang digunakan pengguna untuk suatu dokumen. (Saneifar, 2014)

$\mathrm{Xu}$ dan Croft (2000) memperkenalkan metode query expansion dengan gabungan metode lokal (relevance feedback) dan metode global, yang disebut local context analysis. Pada metode yang mereka ajukan, pemilihan term ekspansi ditingkatkan dengan mempertimbangkan konsep dalam dokumen peringkat atas (top-rank) yang sering memuat banyak term query di seluruh koleksi. Dibandingkan dengan relevance feedback klasik, kandidat term ekspansi lebih relevan dengan query, karena term tersebut telah diteliti sering muncul pada dokumen.

\section{Metode yang diusulkan}

Secara garis besar, tahapan query expansion dapat dilihat pada Gambar 1. Query awal yang dimasukkan oleh pengguna diperluas menggunakan langkah explicit feedback. Pada tahap ini pengguna dapat menentukan perluasan term yang sesuai untuk menjadi query baru (query*). Query* diperluas lagi menggunakan langkah pseudo feedback. Secara otomatis, sistem menentukan term yang sesuai untuk perluasan query sehingga menjadi query**. Pada tahap akhir, pencarian dokumen dilakukan berdasarkan query yang telah diekspasi yaitu query**. Hasil akhir yang diperoleh adalah output dokumen yang relevan.

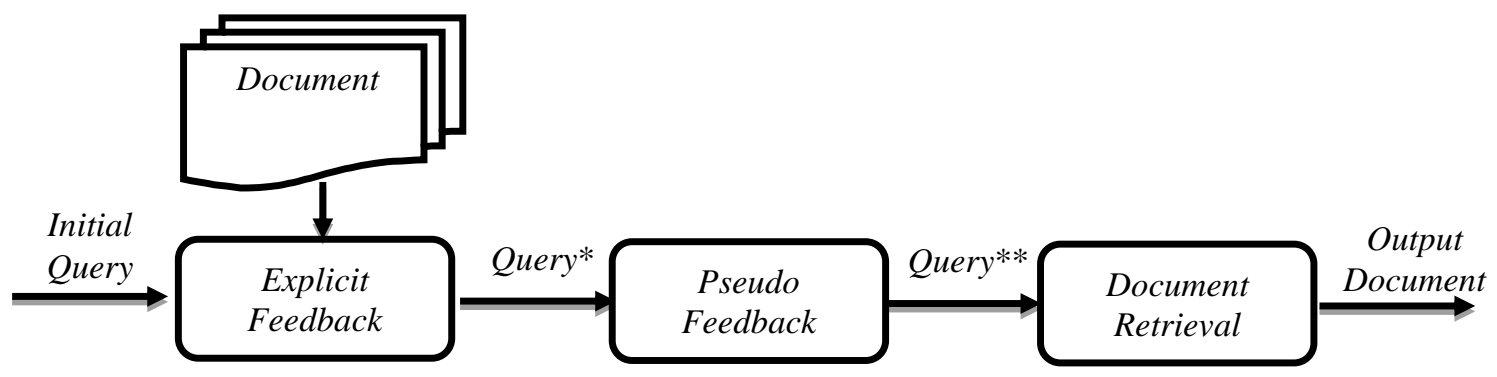

Gambar 1. Diagram Tahapan Query Expansion

\subsection{Explicit Feedback}

Langkah dalam explicit feedback ditunjukkan pada Gambar 2, yaitu dimulai dengan preprocessing, fragmentizing, indexing, pembentukan lexical word, pembobotan, serta pemilihan term untuk ekspansi query. Normalisasi dokumen dan query dilakukan dengan tahapan preprocessing text, yaitu dengan melakukan pemotongan teks dokumen menjadi kumpulan kata (tokenizing), menghilangkan kata yang tidak representatif (stopword removal), dan menjadikan kata berimbuhan menjadi akar kata (stemming).

Fragmentizing serta indexing term dokumen dan query diperlukan untuk membentuk lexical word. Fragmentizing merupakan pemenggalan dokumen menjadi beberapa penggalan kecil. Tiap fragment (penggalan) terdiri dari beberapa term. Pada penelitian ini, tiap fragment terdiri dari paling banyak sepuluh term. Sedangkan lexical word merupakan penggalan kecil (small fragment) dari dokumen yang memuat term query. Tujuan pembentukan lexical word adalah untuk menentukan nilai semantik dari suatu term. Beberapa term yang berada dalam suatu fragment secara umum memiliki hubungan kontekstual atau semantik yang kuat. Sehingga dengan lexical word dapat diidentifikasi kumpulan term yang muncul di sekitar suatu term dalam dokumen.

Pada tahap pembobotan, dilakukan perhitungan bobot term menggunakan pembobotan TF-IDF (Term frequency - invers document frequency) untuk tiap term dalam kumpulan lexical word. Pada tahap ini lexical word yang telah dibentuk dianggap sebagai dokumen. Bobot tiap term diurutkan dan dipilih sejumlah term dengan nilai bobot tertinggi. Berdasarkan term dengan nilai bobot tertinggi itulah pengguna memilih term yang dianggap relevan. Term yang terpilih tersebut menjadi perluasan term query sehingga menghasilkan query baru (query*). 


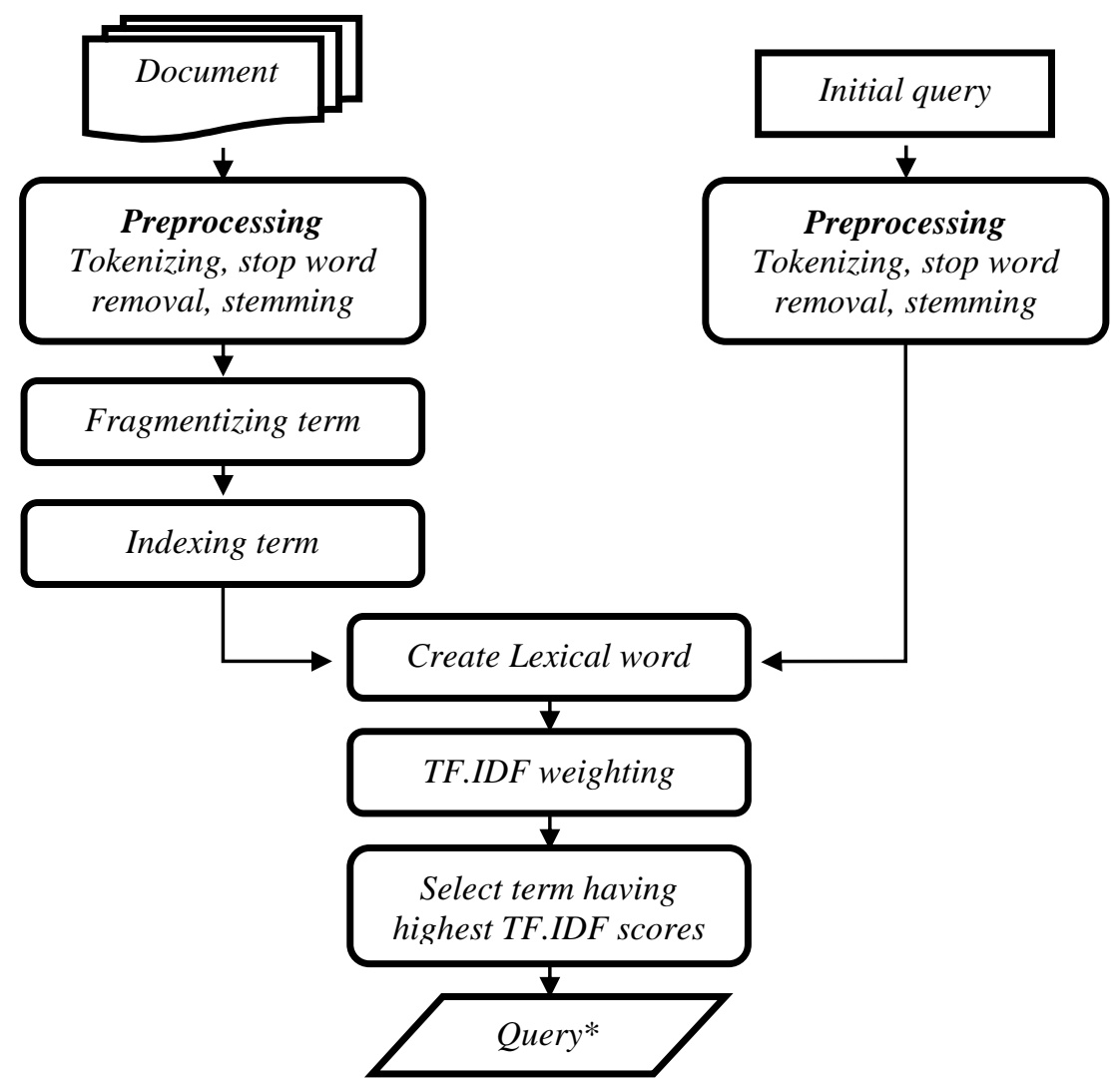

Gambar 2. Tahapan Explicit Feedback

\subsection{Pseudo Feedback}

Query* sebagai hasil dari tahap sebelumnya diperluas lagi dengan pseudo feedback. Metode pembobotan term yang digunakan pada tahap ini adalah pembobotan TRQE (Term Relatedness to Query - Entropy based). Ide dari metode yang diajukan berdasarkan penelitian sebelumnya yang menggunakan pembobotan TRQ. Pembobotan TRQ memberikan nilai lebih pada term yang berhubungan dengan query. Rumusan dari TRQ memadukan antara perhitungan IDF (invers document frequency) dengan LWF (lexical word frequency), dimana formula lwf menggunakan Persamaan 1 dan TRQ dihitung menggunakan Persamaan 2. Notasi K pada Persamaan 1 adalah jumlah query keyword dan $\mathrm{K}_{\mathrm{i}}$ adalah jumlah query keyword yang berhubungan dengan lexical word $i$. Konstanta $\alpha$ digunakan untuk mengatur keberimbangan bobot LWF dan IDF. Berdasarkan ekperimen yang dilakukan oleh Saneifar (2014) hasil optimal ketika $\alpha=0,25$.

$$
l w f_{t i}=\frac{1}{1+\log \left(\frac{K}{K_{i}}\right)}
$$

$T R Q_{t i}=\alpha \times l w f_{t i}+(1-\alpha) \times i d f_{t}$ $\alpha \in[0,1]$

Tujuan utama entropi adalah menghitung jumlah rata-rata informasi yang diperlukan untuk mengidentifikasi label kelas di data training. Pendekatan query expansion berbasis entropi mempertimbangkan distribusi term yang muncul dalam dokumen yang relevan dan tidak relevan hingga sampai pada nilai diskriminasi term. Proporsi kemunculan term dalam dokumen 
yang relevan dan tidak relevan ditunjukkan pada Persamaan 3 sedangkan perhitungan nilai entropi ditunjukkan pada Persamaan 4. $G_{R}$ menunjukkan jumlah informasi dalam dokumen yang relevan, sedangkan $G_{R N}$ menunjukkan jumlah informasi dalam dokumen yang tidak relevan. $\mathrm{R}$ adalah jumlah dokumen yang relevan, dan $R_{N}$ adalah jumlah dokumen yang tidak relevan. $R_{o}$ menunjukkan jumlah dokumen yang relevan yang memuat term tertentu, dan $\mathrm{R}_{\mathrm{q}}$ menunjukkan jumlah dokumen relevan yang tidak memuat term tertentu. Demikian pula, $\mathrm{R}_{\mathrm{NO}}$ menunjukkan jumlah dokumen tidak relevan yang memuat term tertentu, dan $\mathrm{R}_{\mathrm{Nq}}$ menunjukkan jumlah dokumen tidak relevan yang tidak memuat term tertentu.

$$
\begin{aligned}
& G_{R}= \begin{cases}-\frac{R_{0}}{R} \log _{2} \frac{R_{0}}{R}-\frac{R_{q}}{R} \log _{2} \frac{R_{q}}{R}, & \frac{R_{0}}{R}>\frac{1}{2} \\
1, & \frac{R_{0}}{R} \leq \frac{1}{2}\end{cases} \\
& G_{R N}= \begin{cases}-\frac{R_{N 0}}{R_{N}} \log _{2} \frac{R_{N 0}}{R_{N}}-\frac{R_{N q}}{R_{N}} \log _{2} \frac{R_{N q}}{R_{N}}, & \frac{R_{N 0}}{R_{N}}<\frac{1}{2} \\
1, & \frac{R_{N 0}}{R_{N}} \geq \frac{1}{2}\end{cases}
\end{aligned}
$$

Karakteristik utama dari entropi adalah entropi dapat memperkirakan distribusi dari sample. Dengan demikian, jika term muncul dalam dokumen yang relevan 25 kali, nilai entropi akan sama seperti jika term itu muncul dalam dokumen yang relevan 75 kali. Untuk mengatasi masalah ini, maka diterapkan pengkondisian pada Persamaan 3 dan Persamaan 4. Pada Persamaan $3, \frac{R_{0}}{R}>\frac{1}{2}$ untuk memastikan pemilihan term yang muncul di sebagian besar dokumen dari set dokumen yang relevan. Selain itu, pada Persamaan $4, \frac{R_{N_{0}}}{R_{N}}<\frac{1}{2}$ untuk memastikan bahwa term tersebut tidak muncul dalam sebagian besar dokumen dari set dokumen yang tidak relevan. Nilai term diskriminan dirumuskan dalam Persamaan 5.

$T G_{t}=1-\left(\frac{G_{R}+G_{R N}}{2}\right)$

$T G_{t}$ berarti nilai diskriminasi untuk term $\mathrm{t}$ dengan nilai antara nol hingga satu. Persamaan 5 adalah normalisasi untuk Persamaan 3 dan Persamaan 4. Sebagai contoh, jika term yang relevan, $t$, muncul kurang dari atau sama dengan setengah dari dokumen yang relevan, nilai $G_{R}$ menjadi satu. Demikian pula, jika term yang relevan $t$, juga muncul dalam lebih dari atau sama dengan setengah dari dokumen yang tidak relevan, nilai $\mathrm{G}_{\mathrm{RN}}$ juga menjadi satu. Berdasarkan Persamaan 5, nilai $\mathrm{TG}_{\mathrm{t}}$ akan menjadi nol, yang berarti term $\mathrm{t}$, tidak akan dipilih karena memiliki nilai diskriminasi yang rendah.

Rumusan dari metode yang diajukan pada penelitian ini, yaitu TRQE dapat dilihat pada Persamaan $6 . \mathrm{TG}_{\mathrm{t}}$ yang merupakan nilai diskiminan dari term $\mathrm{t}$ dari kumpulan dokumen relevan dan tiak relevan adalah bobot global yang menggantikan bobot IDF pada Persamaan 2. Pada TRQE disertakan pula faktor bobot lokal dari term yaitu $f_{t}$ (frekuensi term) dengan cara mengalikannya dengan bobot global, lwf dan $\mathrm{TG}_{\mathrm{t}}$. Hasil akhir bobot tiap term diurutkan berdasarkan nilai bobot tertinggi. Term dengan bobot tertinggi menjadi perluasan term query sehingga menghasilkan query baru (query**) sebagai expanded query/enriched query. Langkah pseudo feedback dapat dilihat pada Gambar 3.

$$
T R Q E_{t i}=f_{t} \times\left(\alpha \times l w f_{t i}+(1-\alpha) \times T G_{t}\right)
$$

$\alpha \in[0,1]$ 


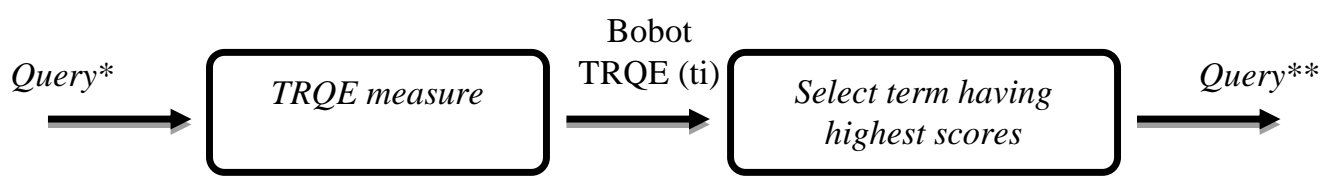

Gambar 3. Tahapan Pseudo Feedback

\subsection{Document retrieval}

Untuk mengembalikan dokumen hasil pencarian berdasarkan query yang telah dikembangkan disini menggunakan pertihungan ukuran kemiripan (similarity). Sebagaimana tahapan yang ditunjukkan pada Gambar 4, pembobotan dilakukan terhadap term document dan

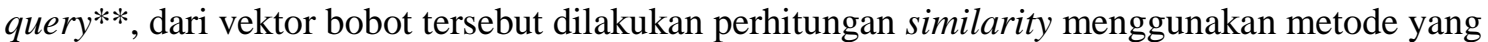
telah banyak digunakan yaitu cosine similarity (Tata, 2007). Dari ukuran kemiripan tersebut maka diperoleh hasil dokumen yang relevan dengan query. Nilai hasil perhitungan cosine similarity berkisar pada nol sampai dengan satu, dimana nol menandakan bahwa kedua dokumen tidak mirip sama sekali, dan satu menandakan bahwa antara query dan dokumen benar-benar identik. Rumusan cosine (Garcia, 2006) dinyatakan sebagaimana Persamaan 7 dimana $\cos \left(q, d_{j}\right)$ merupakan nilai kosinus antara query dan dokumen $j$, sedangkan $\operatorname{TFIDF}\left(t_{k}, q\right)$ dan $T F I D F\left(t_{k}, d_{j}\right)$ adalah pembobotan TFIDF kata $t_{k}$ pada query dan dokumen $j$. |TFIDFq dan $\left|T F I D F d_{j}\right|$ adalah panjang dari vektor query q dan dokumen. Sebagai contoh $\left\|d_{i}\right\|^{2}=\left(\right.$ TFIDFt $_{1}{ }^{2}+$ TFIDFt $_{2}{ }^{2}+$ TFIDFt $_{3}{ }^{2}+\ldots+$ TFIDFt $\left._{k}{ }^{2}\right)^{1 / 2}$, dimana $T F I D F t_{k}$ adalah bobot kata ke- $t_{k}$ pada vektor dokumen $d_{i}$.

$\cos \left(q, d_{j}\right)=\frac{\sum_{t_{k}}\left[\operatorname{TFIDF}\left(t_{k}, q\right)\right] \bullet\left[\operatorname{TFIDF}\left(t_{k}, d_{j}\right)\right]}{\sqrt{\sum|T F I D F q|^{2}} \cdot \sqrt{\sum\left|T F I D F d_{j}\right|^{2}}}$,

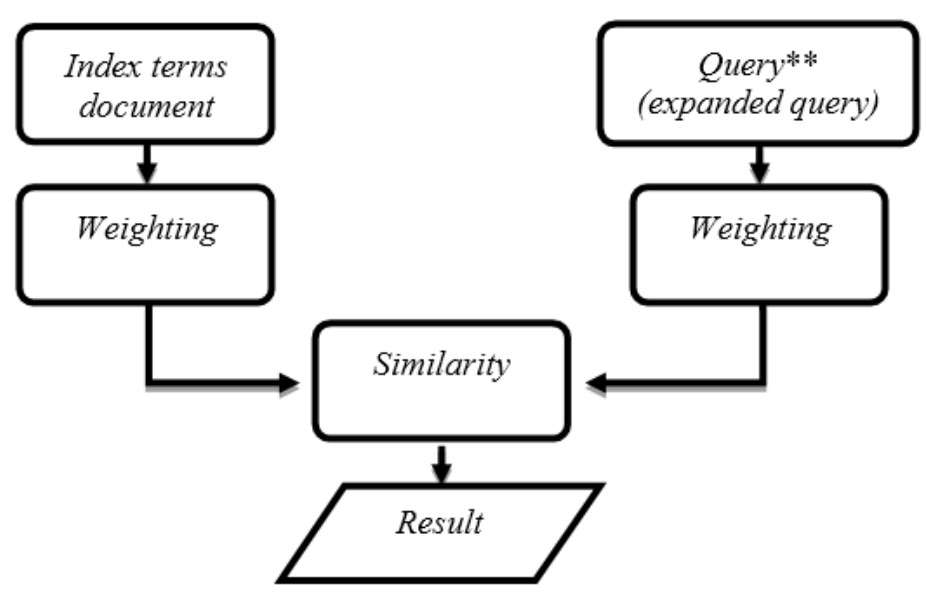

Gambar 4. Tahapan Document Retrieval

Pada penelitian ini, document retrieval dilakukan dengan bantuan library java yang sudah ada yaitu lucene. Library ini bersifat open source dan dapat diunduh di http://lucene.apache.org/.

\section{Skenario dan Hasil Pengujian \\ 4.1. Skenario Pengujian}

Data pengujian berupa dokumen berita berbahasa Inggris yang diambil dari situs New York Times (http://www.nytimes.com/). Dataset yang digunakan berjumlah 20 dokumen, terdiri dari berbagai topik meliputi kesehatan, politik, dan teknologi. Sedangkan kata kunci (query) yang digunakan berjumlah tujuh, digunakan secara konsisten pada pengujian metode ekspansi 
query usulan dengan metode pembanding (TRQE dan TRQ). Query yang digunakan sebagai uji coba pada penelitian ini terdiri dari jumlah yang beragam, mulai dari satu kata hingga enam kata. Query tersebut terbatas pada kata kunci yang relevan dengan topik kesehatan dan politik. Kedua topik tersebut merupakan topik yang berkaitan dengan dataset yang digunakan pada penelitian ini. Sama halnya dengan data pengujian, query yang digunakan juga berbahasa Inggris. Pendapat seorang ahli (expert) digunakan untuk menentukan apakah dokumen hasil pencarian sistem relevan terhadap query yang dimasukkan.

Hasil uji coba pencarian dokumen yang menggunakan metode ekspansi query usulan dengan metode pembanding (TRQE dan TRQ) dievaluasi menggunakan perhitungan recall dan precision (Manning, 2008), seperti pada Persamaan 8 dan Persamaan 9 berikut ini.

precision $=\frac{T P}{T P+F P}$

recall $=\frac{T P}{T P+T N}$

Sebagaimana yang ditunjukkan pada Tabel 1, TP (true positive) merupakan jumlah dokumen yang ter-retrieve secara tepat oleh sistem. FP (false positive) merupakan jumlah dokumen yang tidak tepat ter-retrieve. TN (true negative) merupakan jumlah dokumen relevan yang tidak ter-retrieve. Sedangkan false negative merupakan jumlah dokumen tidak relevan yang tidak ditemukan. Berdasarkan evaluasi menggunakan precission, maka efektivitas dari metode yang digunakan dapat diketahui. Evaluasi dengan recall menunjukkan kemampuan metode dalam mengembalikan dokumen dengan tepat. Hasil evaluasi recall dan precission metode usulan TRQE kemudian dibandingkan dengan metode TRQ untuk dianalisis kemampuan TRQE dalam memperbaiki metode TRQ.

Tabel 1. Recall dan Precision

\begin{tabular}{cccc}
\hline & & \multicolumn{2}{c}{ Document retrieval secara Manual } \\
\cline { 2 - 3 } Document retrieval & Dokumen yang Ditemukan & True Positive & Dokumen yang Tidak Relevan \\
\cline { 2 - 3 } menggunakan TRQE & Dokumen yang Tidak Ditemukan & True Negative & False Negative \\
\hline
\end{tabular}

\subsection{Hasil Pengujian}

Tabel 2 dan Tabel 3 masing-masing menunjukkan hasil ekspansi query menggunakan metode TRQ dan TRQE. Sedangkan hasil pengujian pencarian dokumen ditunjukkan pada Tabel 4.

Tabel 2. Hasil Ekspansi Query Menggunakan Metode TRQ

\begin{tabular}{|c|c|c|c|}
\hline \multirow[t]{2}{*}{ Query } & \multicolumn{2}{|l|}{ Relevan Feedback } & \multirow[t]{2}{*}{ Pseudo Feedback } \\
\hline & Suggestions & Selected query (query*) & \\
\hline Ebola Virus & $\begin{array}{l}\text { - ebola virus parasite } \\
\text { - ebola virus bat } \\
\text { - ebola virus sicken } \\
\end{array}$ & ebola virus parasite & ebola virus parasite \\
\hline Ebola patient & $\begin{array}{l}\text { - ebola patient parasite } \\
\text { - ebola patient bat } \\
\text { - ebola patient sicken }\end{array}$ & Ebola patient & Ebola patient \\
\hline $\begin{array}{l}\text { Respiratory } \\
\text { virus }\end{array}$ & $\begin{array}{l}\text { - respiratory virus parasite } \\
\text { - respiratory virus bat } \\
\text { - respiratory virus sicken }\end{array}$ & $\begin{array}{l}\text { respiratory virus } \\
\text { parasite }\end{array}$ & $\begin{array}{l}\text { respiratory virus parasite } \\
\text { headline }\end{array}$ \\
\hline $\begin{array}{l}\text { Democrate and } \\
\text { Republic party } \\
\text { in election }\end{array}$ & $\begin{array}{l}\text { - democrate republic party election conservative } \\
\text { - democrate republic party election peace } \\
\text { - democrate republic party election arm }\end{array}$ & $\begin{array}{l}\text { democrate republic party } \\
\text { election conservative }\end{array}$ & $\begin{array}{l}\text { democrate republic party } \\
\text { election conservative edition }\end{array}$ \\
\hline Virus & $\begin{array}{l}\text { - virus parasite } \\
\text { - virus bat } \\
\text { - virus sicken }\end{array}$ & virus sicken & virus sicken \\
\hline $\begin{array}{l}\text { Cause of } \\
\text { Children } \\
\text { desease }\end{array}$ & $\begin{array}{l}\text { - child desease secretion } \\
\text { - child desease unconventional } \\
\text { - child desease spread }\end{array}$ & child desease spread & child desease spread \\
\hline
\end{tabular}


Pada Tabel 2, kolom query berisi kata kunci pencarian yang dimasukkan ke sistem. Kolom suggestion berisi saran pencarian (relevan feedback) yang diusulkan oleh sistem, sedangkan kolom selected query (query*) berisi kata kunci pencarian yang dipilih dari relevan feedback. Kolom pseudo feedback berisi perbaikan query di dalam sistem yang tidak ditunjukkan ke pengguna. Sebagai contoh, query yang dimasukkan ke sistem adalah ebola virus. Setelah query tersebut diproses, maka sistem akan mengeluarkan saran pencarian berupa ebola virus parasite, ebola virus bat, dan ebola virus sicken. Dari ketiga saran pencarian tersebut, query yang dipilih adalah ebola virus parasite. Query tersebut kemudian diproses kembali ke sistem sehingga menghasilkan pseudo feedback berupa ebola virus parasite. Query akhir inilah yang digunakan sistem untuk melakukan pencarian dokumen.

Cara membaca Tabel 3 sama dengan Tabel 2. Pembeda kedua tabel tersebut terletak pada metode yang digunakan, Tabel 2 adalah hasil ekspansi query dengan metode TRQ, sedangkan Tabel 3 adalah hasil ekspansi query dengan metode TRQE. Query dan relevan feedback yang diujicobakan sama, tetapi dapat menghasilkan pseudo feedback yang berbeda sesuai dengan algoritma metode masing-masing.

Tabel 3. Hasil Ekspansi Query Menggunakan Metode TRQE

\begin{tabular}{|c|c|c|c|}
\hline \multirow{2}{*}{ Query } & \multicolumn{2}{|l|}{ Relevan Feedback } & \multirow{2}{*}{ Pseudo Feedback } \\
\hline & Suggestions & Selected (query *) & \\
\hline Ebola Virus & $\begin{array}{l}\text { - ebola virus parasite } \\
\text { - ebola virus bat } \\
\text { - ebola virus sicken }\end{array}$ & ebola virus parasite & ebola virus parasite \\
\hline Ebola patient & $\begin{array}{l}\text { - ebola patient parasite } \\
\text { - ebola patient bat } \\
\text { - ebola patient sicken }\end{array}$ & Ebola patient & Ebola patient prodigiously \\
\hline Respiratory virus & $\begin{array}{l}\text { - respiratory virus parasite } \\
\text { - respiratory virus bat } \\
\text { - respiratory virus sicken }\end{array}$ & $\begin{array}{l}\text { respiratory virus } \\
\text { parasite }\end{array}$ & respiratory virus parasite \\
\hline $\begin{array}{l}\text { Democrate and } \\
\text { Republic party in } \\
\text { election }\end{array}$ & $\begin{array}{l}\text { - democrate republic party election conservative } \\
\text { - democrate republic party election peace } \\
\text { - democrate republic party election arm }\end{array}$ & $\begin{array}{l}\text { democrate republic party } \\
\text { election conservative }\end{array}$ & $\begin{array}{l}\text { democrate republic party } \\
\text { election conservative }\end{array}$ \\
\hline Virus & $\begin{array}{l}\text { - virus parasite } \\
\text { - virus bat } \\
\text { - virus sicken }\end{array}$ & virus sicken & virus sicken \\
\hline $\begin{array}{l}\text { Cause of } \\
\text { Children desease }\end{array}$ & $\begin{array}{l}\text { - child desease secretion } \\
\text { - child desease unconventional } \\
\text { - child desease spread }\end{array}$ & child desease spread & child desease spread \\
\hline
\end{tabular}

Tabel 4 berikut ini menunjukkan hasil evaluasi recall dan precission metode TRQ dan TRQE. Berdasarkan hasil tersebut, TRQE kemudian dibandingkan dengan TRQ untuk mengetahui apakah metode tersebut dapat memperbaiki metode pembandingnya atau tidak.

Tabel 4. Hasil Evaluasi Recall dan Precission

\begin{tabular}{crrrr}
\hline Query ke- & \multicolumn{2}{c}{ TRQ } & \multicolumn{2}{c}{ TRQE } \\
\cline { 2 - 5 } & recall\% & precision\% & recall\% & precision\% \\
\hline 1 & 22.22 & 100.00 & 22.22 & 100.00 \\
\hline 2 & 22.22 & 100.00 & 22.22 & 100.00 \\
\hline 3 & 5.26 & 50.00 & 5.26 & 50.00 \\
\hline $\mathbf{4}$ & $\mathbf{2 5 . 0 0}$ & $\mathbf{5 0 . 0 0}$ & 10.00 & 100.00 \\
\hline 5 & 10.00 & 100.00 & 5.26 & 50.00 \\
\hline 6 & 5.26 & 50.00 & 22.22 & 100.00 \\
\hline 7 & 22,22 & 100.00 & &
\end{tabular}

\section{Diskusi}

Berdasarkan hasil pengujian pada Tabel 2 dan Tabel 3, dapat dilihat beberapa ekspansi query yang dihasilkan menghasilkan query* yang. Seperti pada uji coba ke-4, yaitu ketika query yang dimasukkan adalah democrate and republic party in election. Pada ekspansi query TRQ (Tabel 2), pseudo feedback yang dihasilkan adalah democrate republic party election conservative edition. Sedangkan pada ekspansi query TRQE (Tabel 3), pseudo feedback yang dihasilkan adalah democrate republic party election conservative. Adapun beberapa uji coba 
menghasilkan ekspansi query yang sama yaitu pada uji coba 1 , uji coba 5 , uji coba 6 , dan uji coba 7.

Secara umum, hasil evaluasi recall dan precission pada TRQ dan TRQE hampir sama untuk setiap uji coba. Hanya pada uji coba ke-4 yang menghasilkan nilai recall dan precission yang berbeda. Ekspansi query dengan metode TRQE memiliki kemampuan meningkatkan recall dan precision dari metode TRQ. Peningkatan tersebut tampak pada query kedua, dimana TRQ memiliki kemampuan mengembalikan data dengan precision 50\% sedangkan TRQE mampu mengembalikan data dengan nilai precision 57\%. Keenam query lainnya yang diujicobakan tergolong lebih pendek daripada query kedua (query ke-2: democrate and republic party in election). Berdasarkan hasil evaluasi, metode TRQE yang diusulkan terlihat memberikan hasil yang lebih baik untuk query yang relatif lebih panjang.

Entropi mampu mempertimbangkan distribusi term yang muncul dalam dokumen yang relevan dan tidak relevan hingga sampai pada nilai diskriminasi term. Dengan menerapkan konsep entropi pada pembobotan term untuk ekspansi query maka dapat diperoleh term yang tepat sebagai tambahan query. Sehingga ekspansi query lebih optimal dan dapat meningkatkan kemampuan pencarian dokumen. Hal ini tampak pada query kedua, kata "edition" dianggap perlu ditampahkan pada query ketika diukur dengan metode TRQ. Berbeda ketika menggunakan metode TRQE, kata "edition" dinilai tidak tepat untuk ditambahkan pada query. Entropi pada TRQE memperhatikan dokumen relevan dan tidak relevan. Sehingga, kata "edition" yang lebih banyak dimuat pada dokumen tidak relevan tidak dianggap sebagai term yang tepat untuk ditambahkan.

Pada tahap perhitungan entropi diperlukan penentuan kelompok dokumen relevan dan tidak relevan. Penentuan kelompok tersebut didasarkan pada suatu nilai ambang batas yang didapatkan dari rata-rata selisih nilai tertinggi dan terendah TFIDF lexical word terhadap query. Penelitian ini belum menggunakan batas threshold yang optimal dalam menentukan dokumen relevan dan tidak relevan. Beberapa dokumen yang seharusnya relevan dianggap tidak relevan oleh sistem. Hal ini menjadi salah satu faktor yang mempengaruhi hasil metode yang diajukan. Selain itu, keterbatasan data juga mempengaruhi hasil evaluasi, dimana rentang nilai precision untuk setiap uji coba terpaut jauh.

\section{Kesimpulan}

Pada penelitian ini telah diajukan satu metode query expansion yang baru berbasis eksplisit dan pseudo relevance feedback. Metode pembobotan dalam pseudo relevance feedback dalam penelitian ini disebut dengan Term Relatedness to Query - Entropy based (TRQE).Query expansion ini diterapkan dalam document retrieval dengan menggunakan dataset dokumen berita dari New York Times untuk uji coba.

Penambahan entropi untuk pembobotan pada query expansion memberikan pengaruh untuk meningkatkan relevansi pencarian dokumen dengan nilai recall $25,53 \%$ dan presisi $57 \%$. Berdasarkan beberapa query yang diuji, tampak bahwa pembobotan dengan entropi kurang berpengaruh untuk query yang pendek.

Dataset yang diujikan dalam penelitian ini dilakukan pada jumlah dokumen yang terbatas, oleh karena itu perlu adanya ujicoba terhadap jumlah data yang lebih besar dan beragam sehingga pengaruh optimasi ekspansi query terhadap pencarian lebih terlihat.

\section{Referensi}

Agichtein, E., Lawrence, S., \& Gravano, L. 2001. Learning search engine specific query transformations for question answering. In Proceedings of the 10th international conference on World Wide Web (pp. 169-178). ACM.

Araujo, L., Zaragoza, H., Pérez-Agüera, J. R., \& Pérez-Iglesias, J. 2010. Structure of morphologically expanded queries: A genetic algorithm approach. Data \& Knowledge Engineering, 69(3), 279-289.

Boston, C., Fang, H., Carberry, S., Wu, H., \& Liu, X. 2014. Wikimantic: Toward effective disambiguation and expansion of queries. Data \& Knowledge Engineering, 90, 22-37. 
Carpineto, C., De Mori, R., Romano, G., \& Bigi, B. 2001. An information-theoretic approach to automatic query expansion. ACM Transactions on Information Systems (TOIS), 19(1), $1-27$.

Garcia, DR. E., 2006, The Classic Vector Space Model, (Online), (http://www.miislita.com/term-vector/term-vector-3.html, diakses 21 Oktober 2011)

Manning, C. D., Raghavan, P., \& Schütze, H. 2008. Introduction to information retrieval (Vol. 1, p. 6). Cambridge: Cambridge university press.

Pasca, M. A., \& Harabagiu, S. M. 2001. High performance question/answering. In Proceedings of the 24th annual international ACM SIGIR conference on Research and development in information retrieval (pp. 366-374). ACM.

Saneifar, H., Bonniol, S., Poncelet, P., \& Roche, M. 2014. Enhancing passage retrieval in log files by query expansion based on explicit and pseudo relevance feedback. Computers in Industry, 65(6), 937-951.

Tata, Sandeep, Patel M, Jignesh. 2007. Estimating he Selectivity of tf-idf based Cosine similarity Predicates, SIGMOD Record December 2007 Vol 36 No. 2

Wu, I., Chen, G. W., Hsu, J. L., \& Lin, C. Y. (2013). An entropy-based query expansion approach for learning researchers' dynamic information needs. Knowledge-Based Systems, 52, 133-146.

$\mathrm{Xu}$, J., \& Croft, W. B. 2000. Improving the effectiveness of information retrieval with local context analysis. ACM Transactions on Information Systems (TOIS), 18(1), 79-112. 